\title{
Physicians and the pharmaceutical industry: impact on prescription attitudes and habits
}

\author{
Luis Peredo-Silva, ${ }^{1}$ Alberto Lifshitz, ${ }^{2}$ Hortensia Reyes-Morales ${ }^{3}$ and Dolores Mino-León ${ }^{4}$ \\ ${ }^{1}$ Medical, Odontology and Health Sciences Post-degree, Faculty of Medicine, Universidad Nacional Autónoma de México, Mexico City; ${ }^{2}$ Division \\ of Postgraduate Studies, Faculty of Medicine, Universidad Nacional Autónoma de México, Mexico City; ${ }^{3}$ Center of Research in Health Systems, \\ Instituto Nacional de Salud Pública, Cuernavaca, Morelos; ${ }^{4}$ Specialty Hospital, Centro Médico Nacional Siglo XXI, Instituto Mexicano del Seguro \\ Social, Mexico City. Mexico
}

\begin{abstract}
Introduction: The physician-pharmaceutical industry relationship has been identified as an ethical problem, due to conflicts of interest motivated by the benefits that doctors receive and that can affect their clinical judgment. Objective: To identify the frequency of physicians participation in activities financed by the pharmaceutical industry (PI), their attitudes towards PI representatives (PIRs), their prescriptive behavior and the association between their characteristics and their workplace with their participation in activities financed by the PI. Method: Cross-sectional survey to internists and cardiologists. The questionnaire included characteristics of the doctors and their workplace, participation in activities financed by the PI, attitudes towards PIRs, and prescription behavior. Results: 455 questionnaires were analyzed; $78.5 \%$ of surveyed subjects were aware of the physician-PI relationship, the majority acknowledged meeting with PIRs, $30 \%$ indicated having received financial subsidies and $10 \%$ considered that gifts affect their prescription. Having prior knowledge of the physician-PI relationship was associated with less participation in Pl-financed educational activities. Conclusion: Practices and preferences towards the PI show the need to design strategies to avoid inappropriate prescription.
\end{abstract}

KEY WORDS: Pharmaceutical industry. Conflict of interests. Financial support. Prescription patterns. Attitude.

\section{Los médicos y la industria farmacéutica: impacto sobre actitudes y hábitos de prescripción}

\section{Resumen}

Introducción: La relación médico-industria farmacéutica (IF) se ha identificado como un problema ético por favorecer conflictos de interés derivados de los beneficios que reciben los médicos y que pueden afectar su juicio clínico. Objetivo: Identificar la frecuencia de participación de médicos en actividades financiadas por la IF, las actitudes de estos profesionales hacia los representantes de la IF, su conducta prescriptiva y la asociación de sus características y del trabajo con la participación en actividades financiadas por la IF. Método: Encuesta transversal a médicos internistas y cardiólogos. El cuestionario incluyó características de los médicos y centro de trabajo, participación en actividades financiadas por la IF, actitudes hacia los representantes y conducta de prescripción. Resultados: Se analizaron 455 cuestionarios, $78.5 \%$ de los encuestados tuvo conocimiento de la relación médico-IF, la mayoría respondió reunirse con representantes de la IF, 30 \% indicó haber recibido subsidios financieros y 10 \% consideró que los obsequios afectan su prescripción. Tener conocimiento previo de la relación

Correspondence:

*Dolores Mino-León

E-mail: minod_mx@yahoo.com
Gac Med Mex. 2020;156:546-552

Contents available at PubMed

www.gacetamedicademexico.com

0016-3813/@ 2020 Academia Nacional de Medicina de México, A.C.. Published by Permanyer. This is an open access article under the CC BY-NC-ND license (http://creativecommons.org/licenses/by-nc-nd/4.0/). 
médico-IF se asoció con menor participación en actividades educativas financiadas por por la IF. Conclusión: Las prácticas y preferencias hacia la IF muestran la necesidad de diseñar estrategias para evitar la prescripción inapropiada.

PALABRAS CLAVE: Industria farmacéutica. Conflicto de intereses. Apoyo financiero. Patrones de prescripción. Actitud.

\section{Introduction}

In recent decades, the relationship that is established between the physician and the pharmaceutical industry (PI) has become a matter of reflection. Companies use marketing strategies to promote their products, one of which is to employ representatives who interact with the doctor. In the United States of America, nearly $81,000 \mathrm{PI}$ representatives (PIR) have been reported to exist, and each one visits five to ten doctors every day. ${ }^{1}$ In addition, it has been documented that the PI spends around 57 billion dollars annually on promotion and advertising, ${ }^{2}$ and that the physician potentially assumes an attitude of reciprocity for the benefits he/she receives deriving from the interaction with the $\mathrm{PI}$ in conferences and/or hospital-office visits or for accepting gifts, which can affect his/her clinical judgment. ${ }^{2-3}$ The physician adopts a positive attitude towards the $\mathrm{PI}$, which negatively influences his/her behavior and decision-making for the prescription of drugs. $^{2}$ This has been confirmed in a recent study that identified a relationship between attendance at one or several meals sponsored by the PI and an increase in the prescription of the drug it promotes. ${ }^{4}$ In addition, having a high rate of drug prescription has been reported to be a risk factor for the doctor to hold more meetings with PIRs, a behavior that has been identified more frequently in internists and cardiologists, which has been attributed to the type of patients they look after. ${ }^{5}$ Another behavior that has been described as a result of interaction with the PI, is that the physician does not always perceive the influence the $\mathrm{PI}$ exerts on him/her, but does recognize it in his/her colleagues. ${ }^{6}$ Moreover, physicians sometimes are not aware that there is a conflict of interest when they establish a relationship with the $\mathrm{Pl}$, and even consider that the information provided by PIRs keeps them informed about new pharmaceutical products and do not question their quality. ${ }^{7}$

Mexico is an important pharmaceutical market for international companies, mainly of North American origin, and represents the second most important place in Latin America, with almost 300 companies in operation. ${ }^{8}$ In spite of this, the subject has not been sufficiently studied, which is why the research herein presented was carried out, with the purpose to know the frequency and type of participation of internists and cardiologists in Pl-financed activities, to identify their attitudes with regard to PIRs, to determine if there is a correlation between physicians' attitudes and participation in PI-financed activities, to describe the degree of participation in PI-financed activities and the prescribing behavior and to identify if there is an association between the characteristics of the physician or his/her work center and participation in $\mathrm{Pl}$-financed activities.

\section{Method}

During November 2017, a cross-sectional survey was conducted among internal medicine specialists who attended the $40^{\text {th }}$ National Congress of Internal Medicine (Mexico) and cardiology specialists whose email is available at electronic pages of academic organizations of the specialty.

The information was obtained using the questionnaire designed and validated by Saito et al., ${ }^{9}$ which was directly and inversely translated and whose content and linguistic quality were subsequently evaluated by three internists and one cardiologist. The questionnaire was self-administered and anonymous. Consecutive non-probabilistic sampling was performed until a sample that ensured a $95 \%$ confidence level with a margin of error of $5 \%$ was obtained, and it was based on a population of 5,353 certified cardiologists and internists. ${ }^{10}$

The questionnaire includes four sections with the following subjects:

I. Characteristics of physicians and their work center, which are addressed with three questions that explore the regulations for interaction with PIRs restrictions, knowledge on the relationships between physicians and PIRs, and critical reading skills on the subject of medical treatments.

II. Participation in Pl-financed activities. Reception of financial or in-kind benefits granted by the $\mathrm{Pl}$ is identified with seven questions.

III. Attitudes towards PIRs. This section consists of three components: the first one explores the 
informative value the physician confers to PIRs, the second identifies immunity to PIRs actions with regard to prescription habits, both with three questions; and the third one evaluates if the physician considers it is appropriate to receive gifts of monetary value from PIRs.

IV. Prescribing behavior, which is identified by four questions aimed at exploring the behavior with regard to new available drugs, response to patient expectations of receiving a prescription, the degree of satisfaction when choosing not to prescribe and preference for branded or generic drugs.

\section{Study description}

The recruitment of internists was carried out by direct invitation by two researchers during the congress academic activities breaks. Those who accepted, after verbal informed consent, were asked to fill out the questionnaire. Via email, the cardiologists were invited to fill out the informed consent letter and the questionnaire, using the Google Forms tool.

\section{Statistical analysis}

Physicians' and work center characteristics, participation in $\mathrm{Pl}$-financed activities and attitudes absolute frequencies and percentages were estimated. A promotional activity index was generated considering the frequency at which the physician participated in PI-financed activities in one month, with the mean \pm standard deviation (SD) being calculated. To grade the physician's attitude, the procedures recommended in the original version of the questionnaire were followed, ${ }^{9}$ where a 0 to 1 scale is used, with higher scores representing PIRs better evaluation. Subsequently, the numerical scale of the attitude components answers was used and the mean \pm SD was calculated. To measure the correlation between each component of the promotional activity index and physicians' attitudes scores, Spearman's correlation coefficient was used. To contrast the promotional activity index medians with prescription behaviors, Mann Whitney's U-test was used. The answers to the prescription behaviors questions were reclassified into two options; the category that revealed that promotional activities have an impact on physicians' prescription behavior was highlighted. A $p$-value $<0.05$ was regarded as significant.
Simple and adjusted models were developed to identify associations between work center characteristics (rules that ban gifts or meetings with PIRs), knowledge about relationships between physicians and PIRs, critical reading skills on the subject of medical treatments and participation in Pl-financed continuing medical education (CME) activities. The logistic regression models were adjusted for gender, years of practicing medicine, number of jobs, specialty, and valid specialty certification. To perform the statistical analysis, the SPSS program, version 21, was used.

The protocol was authorized by the Research and Ethics Committees of the National Institute of Geriatrics with registration number DI-PI-002/2017.

\section{Results}

Four-hundred and eighty-six questionnaires were applied, out of which 31 were excluded. Most participants were internal medicine specialists and $85 \%$ of the entire sample reported practicing in a hospital, although half of them also indicated serving at private practice. Regarding the work center characteristics, the fact that two-thirds of the physicians answered that there are no rules that ban meeting with PIRs and/or receiving gifts from them stood out. More than $75 \%$ referred being aware of the physician-PI relationship, and almost all surveyed subjects indicated having learned skills to critically read medical literature on the subject of pharmacological treatments (Table 1).

Regarding physicians' participation in Pl-financed activities, almost the totality accepted that they hold meetings with PIRs, twice monthly on average. The majority also reported frequently receiving drug samples, at an average of once weekly. Two thirds referred attending $\mathrm{PI}$-sponsored $\mathrm{CME}$ events within their workplace and the same proportion outside of it, and among them, about half reported receiving financial subsidies to attend said events (Table 2).

More than half the participants considered that PIRs play an important role in CME and provide accurate information on new drugs. In contrast, only one out of every ten doctors considered that gifts can have a negative effect on their prescription behavior, although one out of every four answered that this fact negatively impacts the prescription behaviors of their colleagues and one third of them considered receiving gifts of high monetary value to be inappropriate (Table 3). 
Table 1. Characteristics of physicians and their work center

\begin{tabular}{|c|c|c|}
\hline \multirow[t]{2}{*}{ Physicians' characteristics } & \multicolumn{2}{|c|}{ Frequency $(n=455)$} \\
\hline & n & $\%$ \\
\hline $\begin{array}{l}\text { Gender } \\
\text { Females } \\
\text { Males }\end{array}$ & $\begin{array}{l}162 \\
293\end{array}$ & $\begin{array}{l}35.6 \\
64.4\end{array}$ \\
\hline $\begin{array}{l}\text { Time practicing medicine } \\
0-10 \text { years } \\
\geq 11 \text { years }\end{array}$ & $\begin{array}{l}195 \\
260\end{array}$ & $\begin{array}{l}42.9 \\
57.1\end{array}$ \\
\hline $\begin{array}{l}\text { Medical specialty } \\
\text { Internal Medicine } \\
\text { Cardiology }\end{array}$ & $\begin{array}{l}328 \\
127\end{array}$ & $\begin{array}{l}72.1 \\
27.9\end{array}$ \\
\hline $\begin{array}{l}\text { Work center } \\
\text { Hospital } \\
\text { Private practice } \\
\text { Other }\end{array}$ & $\begin{array}{c}387 \\
242 \\
32\end{array}$ & $\begin{array}{c}85.0 \\
53.2 \\
7.0\end{array}$ \\
\hline $\begin{array}{l}\text { Valid council certification } \\
\text { Yes } \\
\text { No }\end{array}$ & $\begin{array}{l}262 \\
193\end{array}$ & $\begin{array}{l}57.6 \\
42.4\end{array}$ \\
\hline $\begin{array}{l}\text { Work center characteristics } \\
\text { There are rules that ban gifts, but not meetings with PIRs* } \\
\text { There are rules that ban meetings, but not gifts. } \\
\text { There are rules that ban gifts and meetings. } \\
\text { There are no rules for gifts or meetings. }\end{array}$ & $\begin{array}{l}103 \\
31 \\
32 \\
289\end{array}$ & $\begin{array}{c}22.6 \\
6.8 \\
7.0 \\
63.5\end{array}$ \\
\hline $\begin{array}{l}\text { Have you had the opportunity to learn about the relationship between the physician and the PI?** } \\
\text { Yes (very little, little, some and substantial) } \\
\text { No (none) }\end{array}$ & $\begin{array}{c}359 \\
98\end{array}$ & $\begin{array}{l}78.5 \\
21.5\end{array}$ \\
\hline $\begin{array}{l}\text { Have you had the opportunity to learn skills to critically read medical literature, related to pharmacological treatments? } \\
\text { Yes (very little, little, some and substantial) } \\
\text { No (none) }\end{array}$ & $\begin{array}{c}406 \\
49\end{array}$ & $\begin{array}{l}89.2 \\
10.8\end{array}$ \\
\hline
\end{tabular}

Table 2. Frequency of participation in promotional activities and promotional activity index

\begin{tabular}{|c|c|c|c|}
\hline \multirow[t]{2}{*}{ Actividad promocional } & \multicolumn{2}{|c|}{$\begin{array}{l}\text { Frequency } \\
(\mathrm{n}=455)\end{array}$} & \multirow{2}{*}{$\begin{array}{c}\begin{array}{c}\text { Promotional activity index } \\
\text { (days/month) }\end{array} \\
\text { Mean } \pm \text { SD }\end{array}$} \\
\hline & n & $\%$ & \\
\hline Meeting with PIRs & 365 & 80.2 & $2.51 \pm 3.88$ \\
\hline Receiving drug samples & 383 & 84.2 & $3.88 \pm 5.44$ \\
\hline Receiving stationery (pens, notebooks, etc.) & 393 & 86.4 & $2.95 \pm 4.25$ \\
\hline Attending PI-financed meals outside the workplace & 260 & 57.1 & $0.96 \pm 2.06$ \\
\hline Attending PI-financed CME meetings within the workplace & 277 & 60.9 & $1.14 \pm 2.27$ \\
\hline Attending Pl-financed CME meetings outside the workplace & 266 & 58.5 & $0.91 \pm 1.95$ \\
\hline Receiving financial subsidies to attend CME events & 130 & 28.6 & $0.50 \pm 1.79$ \\
\hline
\end{tabular}

$\mathrm{CME}=$ continuing medical education; $\mathrm{PI}=$ pharmaceutical industry; $\mathrm{PIRs}=$ pharmaceutical industry representatives; $\mathrm{SD}=$ standard deviation.

Average score of the "informative value" component was $0.57 \pm 0.26$, which meant that the physician considers that the information provided by PIRs is valuable; for the "immunity" component, it was $0.64 \pm$ 0.23 , which showed that most physicians consider themselves immune to being influenced on their 
Table 3. Frequency of physicians' attitudes with regard to PIRs in the informative value, immunity and appropriateness components

\begin{tabular}{|c|c|c|c|}
\hline Component & $\begin{array}{c}\text { Agree } \\
(\%)\end{array}$ & $\begin{array}{c}\text { Neutral } \\
(\%)\end{array}$ & $\begin{array}{c}\text { Disagree } \\
(\%)\end{array}$ \\
\hline $\begin{array}{l}\text { Informative value } \\
\text { PIRs play an important role in physicians' CME } \\
\text { PIRs provide accurate information on new drugs } \\
\text { PIRs provide accurate information on old marketed drugs }\end{array}$ & $\begin{array}{l}55.8 \\
51.9 \\
44.0\end{array}$ & $\begin{array}{l}25.9 \\
19.3 \\
22.0\end{array}$ & $\begin{array}{l}18.3 \\
28.8 \\
34.0\end{array}$ \\
\hline $\begin{array}{l}\text { Immunity } \\
\text { Dialogue with PIRs has an unfavorable impact on my prescription habits } \\
\text { Gifts granted by PIRs, regardless of their commercial value, have an unfavorable impact on } \\
\text { my prescription habits. } \\
\text { Gifts granted by PIRs, regardless of their commercial value, have an unfavorable impact on } \\
\text { other physicians' prescription habits. }\end{array}$ & $\begin{array}{l}17.8 \\
10.3 \\
23.7\end{array}$ & $\begin{array}{l}41.3 \\
35.7 \\
34.9\end{array}$ & $\begin{array}{l}40.9 \\
54.0 \\
41.3\end{array}$ \\
\hline $\begin{array}{l}\text { Appropriateness } \\
\text { It is appropriate to receive low monetary value gifts from PIRs } \\
\text { It is appropriate to receive high monetary value gifts from PIRs }\end{array}$ & $\begin{array}{l}28.8 \\
24.1\end{array}$ & $\begin{array}{l}44.6 \\
39.8\end{array}$ & $\begin{array}{l}26.6 \\
36.1\end{array}$ \\
\hline
\end{tabular}

prescription behavior; for the "appropriate" component, average was lower $(0.46 \pm 0.27)$, which showed that gifts from PIRs were deemed inappropriate by physicians. No correlation was observed between the components of physicians' attitude and the promotional activity index ("informative value", $r=0.01, p=0.70$; "immunity", $r=0.03, p=0.43$; and "appropriate", $r=0.06, p=0.15$ ) (Data not shown in table).

Regarding prescription behaviors, most physicians answered that when a new drug is being marketed, they seek results on its effectiveness and only less than $5 \%$ referred obtaining the information from PIRs. When asked about patient expectations about receiving a prescription, more than $75 \%$ answered that that they agreed on providing it without explaining that it is not clinically indicated, and almost the same proportion answered being satisfied when choosing not to prescribe; regarding the preference for the type of drugs, only one out of every four physicians leaned towards a generic drug, one out of every five preferred a branded drug and half of them showed no preference (Table 4).

When the promotional activity index medians were contrasted with prescription behaviors, a difference was only detected in the prescription behavior regarding branded drugs vs. generic drugs or neutral position (8.5 vs. $7.0 ; p=0.01$ ). In the crude data analysis, an association was observed between having had the opportunity to learn about physician-PI relationships and less participation in PI-financed CME activities, an association that prevailed in the adjusted logistic regression model (adjusted for gender, years of practicing medicine, number of jobs, specialty and valid specialty certification) with an odds ratio $=0.39,95 \%$ confidence interval $=0.21-0.72$ and $p$-value $=0.00$ (Table 5).

\section{Discussion}

As reported in the literature, PIRs office visits and receiving drug samples or gifts can affect the quality of medical prescription, given that prescription of branded drugs, which are costly and put effective and economic options aside, is promoted. ${ }^{11}$ We observed this situation in the presented research, since, on one hand, most physicians considered themselves immune to the influence of PIRs on the prescription of drugs; however, physicians who referred prescribing branded drugs despite having a generic alternative showed the highest participation in PI promotional activities. Similar findings have been reported in a previous study that included physicians in a different clinical practice and cultural context from that of the present work, ${ }^{9}$ which can be explained if we consider that the $\mathrm{PI}$ is a conglomerate of multinational companies that are part of a globalized system and that one of their purposes is to sell medicines in most part of the world, whereby they use similar promotional strategies. ${ }^{12}$

On the other hand, an elevated proportion of surveyed physicians prescribed drugs despite not having clinical justification; the argument was that they did not feel satisfied if they concluded a patient consultation without prescribing a drug. Both results may suggest that the physician gives priority to the prescription of a drug over patient safety, an attitude that is probably due to the constant relationship with PIRs. Another important result is that, when the physician has prior 
Table 4. Frequency of prescription behaviors

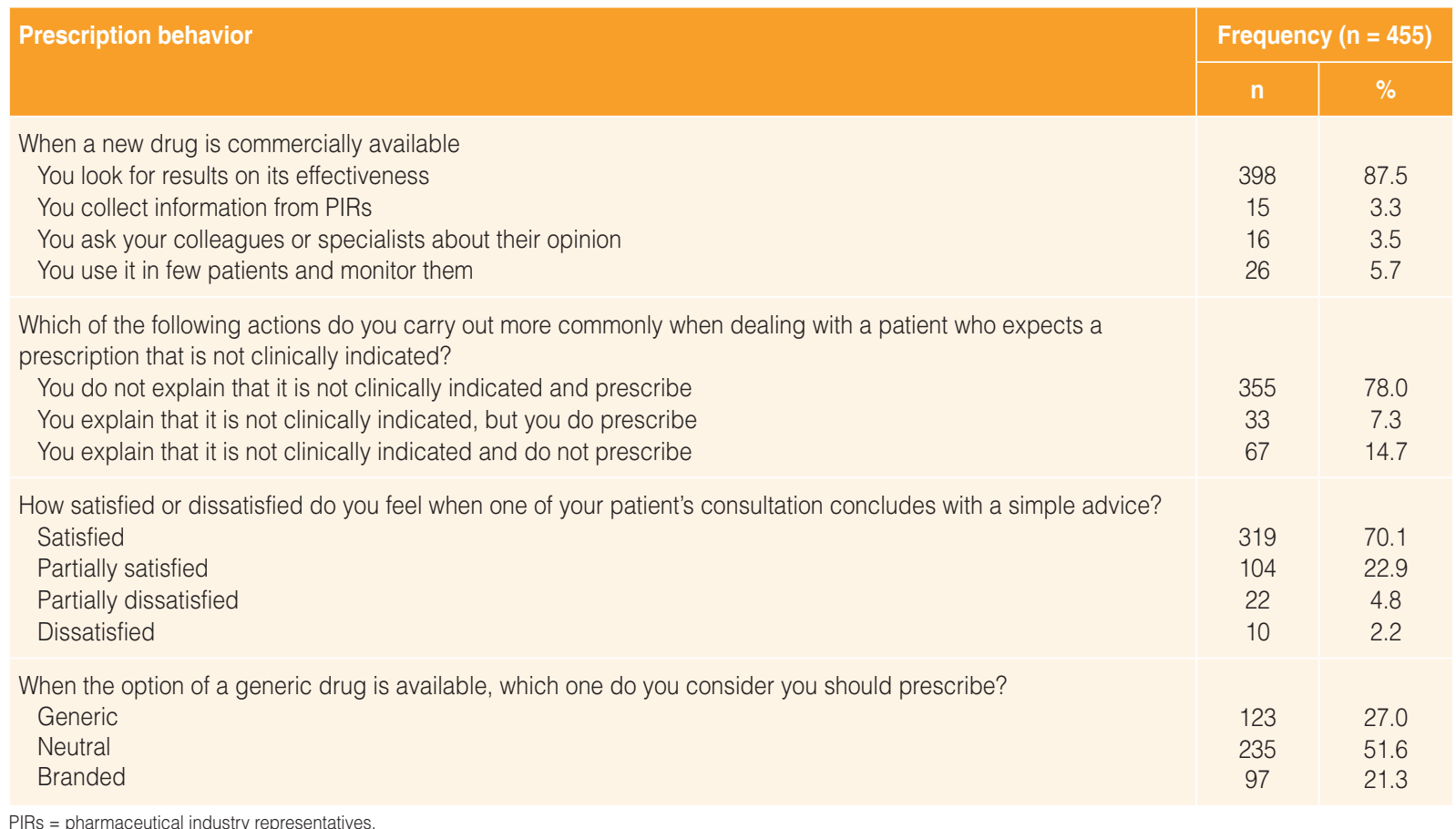

Table 5. Personal and work center characteristics adjusted associations with physician's participation in PI-sponsored activities

\begin{tabular}{|c|c|c|c|c|}
\hline \multirow[t]{2}{*}{ Variables } & \multirow[t]{2}{*}{ PR } & \multicolumn{2}{|c|}{$95 \% \mathrm{Cl}$} & \multirow[t]{2}{*}{ p } \\
\hline & & Lower & Upper & \\
\hline Gender & 0.843 & 0.539 & 1.318 & 0.454 \\
\hline Time practicing medicine & 0.799 & 0.509 & 1.254 & 0.329 \\
\hline Number of jobs & 1.274 & 0.802 & 2.025 & 0.305 \\
\hline Specialty & 0.826 & 0.526 & 1.295 & 0.405 \\
\hline Specialty council valid certification & 0.784 & 0.505 & 1.217 & 0.278 \\
\hline Rules at work center to participate in PI-sponsored activities & 0.879 & 0.573 & 1.348 & 0.555 \\
\hline Opportunity to learn about the relationship between the physician and the PI & 0.392 & 0.212 & 0.725 & 0.003 \\
\hline $\begin{array}{l}\text { Opportunity to acquire skills to critically read medical literature related to pharmacological } \\
\text { treatments }\end{array}$ & 1.371 & 0.852 & 2.206 & 0.194 \\
\hline
\end{tabular}

information about the physician-PI relationship, this becomes a "protective" factor against getting involved in PI-funded activities and, consequently (according to that which has been consistently mentioned in the literature for more than two decades ${ }^{2,13-15}$ ), the impact of these activities on physicians' prescription behaviors is decreased; however, the fact that some studies have documented physicians' lack of identification of the difference between promotional information and scientific evidence should be considered..$^{16-18}$
This is relevant, since despite the fact that, in this work, a considerable proportion of physicians indicated to have skills to critically read medical literature, an elevated proportion of them answered that the information provided by PIRs has informative value and is accurate, in addition to considering that PIRs play a considerable role in their CME. These data reveal that it is necessary to improve the knowledge of physicians about published information quality assessment, with an emphasis on clinical trials. 
Another result that is important to emphasize is that related to gifts granted by the $\mathrm{PI}$. In this sense, the proportion of physicians who accepted them was similar to that reported by other authors, ${ }^{4,9,18,19}$ in addition, those physicians considered that this fact does not influence their prescription behavior, but it does influence that of their colleagues, an opinion that is similar to that documented in another study. ${ }^{6}$

Finally, some limitations of this work should be recognized, such as the procedure to select the participants, which does not allow assuming that they represent the physicians from the included specialties. In addition, the questionnaire that was used was designed in a different context to that of the present study and its content validity was verified by consensus.

\section{Conclusion}

The findings allow identifying frequent practices and preferences in the medical field in Mexico, and show the need to explore this issue in depth, owing to its ethical and patient safety implications, as well as to design strategies to ensure that the potential relationship of the medical community with the pharmaceutical industry does not affect the decision when prescribing a drug.

\section{Conflicts of interest}

The authors declare that they have no conflicts of interest.

\section{Funding}

The authors did not receive any sponsoring to carry out this article.

\section{Ethical disclosures}

Protection of human and animal subjects. The authors declare that no experiments were performed on humans or animals for this research.
Confidentiality of data. The authors declare that no patient data appear in this article.

Right to privacy and informed consent. The authors declare that no patient data appear in this article.

\section{References}

1. Weiss JA. Medical marketing in the United States: a prescription for reform. George Washington Law Review. 2010;79:260.

2. Gagnon MA, Lexchin J. The cost of pushing pills: a new estimate of pharmaceutical promotion expenditures in the United States. PLoS Med. 2008;5:e1.

3. Fickweiler F, Fickweiler W, Urbach E. Interactions between physicians and the pharmaceutical industry generally and sales representatives specifically and their association with physicians' attitudes and prescribing habits: a systematic review. BMJ Open. 2017;7:e016408.

4. DeJong C, Aguilar T, Tseng CW, Lin GA, Boscardin WJ, Dudley RA. Pharmaceutical industry-sponsored meals and physician prescribing patterns for medicare beneficiaries. JAMA Intern Med. 2016:176:1114-1122.

5. Vallano A, Montané E, Arnau JM, Vidal X, Pallarés C, Coll M, et al. Medical speciality and pattern of medicines prescription. Eur J Clin Pharmacol. 2004;60:725-730.

6. Korenstein D, Keyhani S, Ross JS. Physician attitudes toward industry: a view across the specialties. Arch Surg. 2010;145:570-577.

7. De Ferrari A, Gentille C, Davalos L, Huayanay L, Malaga G. Attitudes and relationship between physicians and the pharmaceutical industry in a public general hospital in Lima, Peru. PLoS One. 2014;9:e100114.

8. Comisión Federal para la Protección contra Riesgos Sanitarios [website]. Mexico: Base de datos de licencias sanitarias de fábricas de medicamentos alopáticos, homeopáticos y herbolarios; 2020.

9. Saito S, Mukohara K, Bito S. Japanese practicing physicians' relationships with pharmaceutical representatives: a national survey. PLoS One. 2010;5:e12193.

10. Heinze-Martin G, Olmedo-Canchola VH, Bazán-Miranda G, Bernard-Fuentes NA, Guízar-Sánchez DP. Los médicos especialistas en México. Gac Med Mex. 2018;154:342-351.

11. King AC, Schwartz LM, Woloshin S. A national survey of the frequency of drug company detailing visits and free sample closets in practices delivering primary care. JAMA Intern Med. 2020;180:592-595.

12. Páez R. Pautas bioéticas. La industria farmacéutica entre la ciencia y el mercado. Mexico: Fondo de Cultura Económica; 2018.

13. Moynihan R. Who pays for the pizza? Redefining the relationships between doctors and drug companies. 1: entanglement. BMJ. 2003; 326:1189-1192.

14. Lexchin J. What information do physicians receive from pharmaceutical representatives? Can Fam Physician. 1997;43:941-945.

15. Sharma M, Vadhariya A, Johnson ML, Marcum ZA, Holmes HM. Association between industry payments and prescribing costly medications: an observational study using open payments and medicare part $D$ data. BMC Health Serv Res. 2018;18:236.

16. Othman N, Vitry Al, Roughead EE, Ismail SB, Omar K. Medicines information provided by pharmaceutical representatives: a comparative study in Australia and Malaysia. BMC Public Health. 2010;10:743.

17. Mulinari S. Unhealthy marketing of pharmaceutical products: an international public health concern. J Public Health Policy. 2016;37:149-159.

18. Lieb K, Brandtönies S. A survey of German physicians in private practice about contacts with pharmaceutical sales representatives. Dtsch Arztebl Int. 2010;107:392-398.

19. Anderson BL, Silverman GK, Loewenstein GF, Zinberg S, Schulkin J. Factors associated with physicians' reliance on pharmaceutical sales representatives. Acad Med. 2009;84:994-1002. 